\title{
iTRAQ-Based Proteomic Analysis of Neonatal Kidney from Offspring of Protein Restricted Rats Reveals Abnormalities in Intraflagellar Transport Proteins
}

\author{
Xiaomei Liu ${ }^{a, b}$ Jun Wanga,b,c Linlin Gao ${ }^{d}$ Hao Liu ${ }^{a}$ Caixia Liu

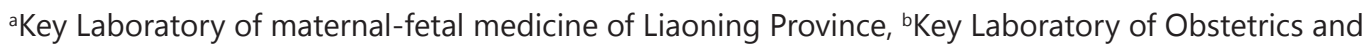 \\ Gynecology of Higher Education of Liaoning Province, Department of Obstetrics and Gynecology, \\ Shengjing Hospital of China Medical University, ${ }^{c}$ Department of Obstetrics and Gynecology, Benxi \\ Central Hospital of China Medical University, Benxi, dMedical Research Center, Shengjing Hospital, \\ China Medical University, Shenyang, PR China
}

\section{Key Words}

Prenatal nutrition • Kidney • iTRAQ • IUGR • Offspring

\begin{abstract}
Background: It is well recognized that adverse events in utero can impair fetal development and lead to the development of kidney injury and hypertension in adulthood. We previously reported a lower kidney index, glomeruli number, and decreased glomerular filtration rate in intrauterine growth restriction (IUGR) offspring induced by maternal protein malnutrition. To explore the molecular mechanisms linking impaired fetal growth to renal diseases, we investigated differentially expressed proteins (DEPs) in the IUGR neonatal kidneys by isobaric tags for relative and absolute quantitation (iTRAQ) analysis. Methods: We induced IUGR through maternal protein malnutrition. Neonatal kidneys were collected; the protein was extracted; pooled before iTRAQ labeling, and subjected to mass spectrometric analysis. Mass spectrometry results were then further confirmed by assessing five representative proteins in individual specimens with quantitative PCR (qPCR), immunohistochemical (IHC) and / or western blot analysis. Results: A total of 367DEPs (263 up-regulated, 104 down-regulated.) with a threshold of a 1.2-fold change and a P value $\leq 0.05$ between IUGR kidneys and control kidneys were identified. Further bioinformatics analysis revealed that these proteins play important roles in oxidative phosphorylation, purine metabolism, pyrimidine metabolism, RNA small body, spliceosome assembly and intraflagellar transport (IFT). IFT family proteins (IFT80, 88,144) and PKD2 were shown to be up-regulated in IUGR kidneys, confirmed by western blotting, IHC and Q-PCR. Epigenetic modulating factors SET and MYND domain containing 3 (SMYD3), a histone-lysine N-methyltransferase, and H3K4me3 level were also remarkably enhanced in IUGR neonatal kidneys. Conclusions: This first comprehensive analysis of the neonatal kidney proteome reveals new insights in nephridial development, and may make a valuable contribution towards the identification of the pathological mechanisms involved in the developmental origins of adult disease.

(C) 2017 The Author(s)

Published by S. Karger AG, Basel

Caixia Liu, MD

Key laboratory of maternal-fetal medicine of Liaoning Province, and Key Laboratory of Obstetrics and Gynecology of Higher Education of Liaoning Province, Department of Obstetrics and Gynecology, Shengjing Hospital of China Medical University, Shenyang, 110004, (P. R. China); Tel. / Fax +80-024-96615-43211, E-Mail aiyuanw@yeah.net
\end{abstract}

KARGER 


\section{Cellular Physiology Cell Physiol Biochem 2017;44:185-199

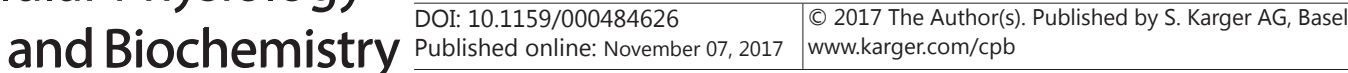 \\ Liu et al.: Proteomics of Neonatal Kidney of IUGR Rats}

\section{Introduction}

Intrauterine growth restriction (IUGR)affects $3 \%-10 \%$ of pregnancies and is recognized as a major cause of fetal and neonatal morbidity and mortality $[1,2]$ Decreased fetal growth rates reflect an adaptation to an adverse in utero environment and may have long-term effects on metabolism, growth and organ development $[3,4]$. Concern over the fetal programming effects of IUGR on the kidney has gained momentum in recent years, as epidemiological and experimental studies have demonstrated a significant association between birth weight and postnatal kidney function. For example, Gray and colleagues reported that IUGR reduces the volume of the fetal kidney and significantly decreases the number of glomeruli, as compared with the normal fetal kidney [5-7]. Based on IUGR models caused by maternal proteinmalnutrition, we previously reported a lower kidney ind ex, glomeruli number, and glomerular filtration rate in IUGR offspring, with an increased incidence of hypertension, as compared with the control group throughout the postnatal follow-up period [8], consistent with other reports $[9,10]$. IUGR has been confirmed as an independent risk factor for the development of chronic nephrite morbidity, but the underlying mechanisms of the programming effect on the fetal kidney remain unknown.

Studies on human and experimental models of fetal programming have unraveled a variety of factors involved in the pathogenesis of hypertension, including altered vascular structure and function, sex hormones, oxidative stress, inflammation and sympathetic regulation [11-16].Vasodilatation was reported to be impaired in low birth weight offspring [13] and children born small for gestational age tend to have increased indices of lipid peroxidation and slightly higher systolic blood pressure, as compared with normal controls $[17,18]$. Experimental data support the hypothesis that programming of hypertension by adverse intrauterine conditions may be secondary to oxidative stress [19]. Data from experimental models and human patients have shown elevations in circulating levels of catecholamines in IUGR offspring, while the contribution of the sympathetic nervous system to fetal programming hypertension remains controversial [20, 21].Sex differences in developmental programming have been confirmed in an epidemiological survey and experimental studies, which have shown that female offspring are more protected from in utero insults [22-24].

The mechanism by which the fetal environment programs hypertension and an increased susceptibility to renal injury may involve either intrinsic or extrinsic renal mechanisms or both. Nevertheless, to date, there have been no reported attempts to screen the regulatory factors involved in kidney development of the IUGR neonate using large-scale proteomic analysis. Therefore, the present study investigated the impact of IUGR on the proteome profile of the neonatal kidney using isobaric tags for relative and absolute quantitation (iTRAQ) technology coupled with two-dimensional nano-liquid chromatography-tandem mass spectrometry(2D LC-MS/MS)to explore possible mechanisms underlying the pathogenesis of IUGR-induced kidney injury.

\section{Material and Methods}

\section{Establishment of the IUGR animal model}

The animal study protocols were approved by the Animal Research Committee of China Medical University. Adult Wistar rats (body weight 230 260 g) were individually housed under specific pathogenfree conditions in an environmentally controlled clean room at the Experimental Animal Center Shengjing Hospital of China Medical University (Shenyang, China).Food and water was provided ad libitum throughout the study period. Female rats were randomly divided into two groups after mating with male rats.The animals in the under-nourished group were fed an isocaloric low-protein diet (7\% protein) from day 0 of pregnancy until the delivery of pups, as we described previously [25], while thecontrol animals were maintained on a conventional diet(23\% protein) during gestation. Here, IUGR refers to newborn rats with a birth weight of at least two standard deviations lower than the average birth weight of normal newborn rats. 
Newborn rats in both groups were delivered spontaneously and nourished by the mothers until weaning at postnatal week $3(3 \mathrm{~W})$ and then fed normal chow (23\% protein) until postnatal week $12(12 \mathrm{~W})$. At day 1 (D1), D7, 3W, and 12W, the pups were killed under ether anesthesia, and the kidneys were dissected, snap frozen in liquid nitrogen, and stored at $-80^{\circ} \mathrm{C}$ until use. To avoid any sex and hormonal confounding interference, all the following analyses were performed with male pups only.

\section{Protein preparation}

The workflow of the study is presented in Fig. 1. Briefly, 24 kidney tissues (12 controls, 12 IUGRs) were homogenized in extraction SDT buffer (4\% sodium dodecyl sulfate (SDS), $1 \mathrm{mM}$ dithiothreitol (DTT), $150 \mathrm{mM}$ Tris-HCl, $\mathrm{pH}$ 8.0). The homogenate was sonicated on ice after 3 min incubation in boiling water. The crude extract was incubated in boiling water again and then clarified by centrifugation at 16,000 $\mathrm{g}$ for $10 \mathrm{~min}$ at $25^{\circ} \mathrm{C}$. The protein content was determined using BCA protein assay reagent (Beyotime Institute of Biotechnology, Haimen, China).Protein samples $(10 \mu \mathrm{g})$ were separated by electrophoresis on $12.5 \%$ SDSpolyacrylamide gels and stained with Coomassie Brilliant Blue to confirm parallelisms among samples. To reduce individual variation, 12 controls were pooled into 3 samples as control1, control2, and control3, and 12 IUGRs were pooled into 3 samples as IUGR1, IUGR2 and IUGR3.

\section{Protein digestion and ITRAQ labeling}

Protein digestion was conducted according to the FASP procedure described by Wisniewski et al. [26]. The resulting peptide mixture was then labeled with 4-plex / 8-plexiTRAQ reagent (Applied Biosystems, Carlsbad, CA, USA), according to the manufacturer's instructions. Briefly, $300 \mu \mathrm{g}$ of proteins isolated from each sample were mixed with $30 \mu \mathrm{L}$ of STD buffer (4\% SDS, $100 \mathrm{mM}$ DTT, $150 \mathrm{mM}$ Tris-HCl, pH 8.0). Then, $200 \mu \mathrm{L}$ of UA buffer (8 M Urea, $150 \mathrm{mM}$ Tris-HCl, $\mathrm{pH}$ 8.0) was used to remove the detergent, DTT, and other low molecular weight components by repeated ultrafiltration (Microcon® Centrifugal Filter, $10 \mathrm{kDa}$; SigmaAldrich Corporation, St. Louis, MO, USA) at $14000 \mathrm{~g}$ for $15 \mathrm{~min}$. Afterward, $100 \mu \mathrm{L}$ of $0.05 \mathrm{M}$ iodoacetamide in UA buffer was added to block the reduced cysteine residues and the samples were incubated in darkness for $30 \mathrm{~min}$. The filters were washed with $100 \mu \mathrm{L}$ of UA buffer three times and then twice with $100 \mu \mathrm{L}$ of DS buffer ( $50 \mathrm{mM}$ triethylammonium bicarbonate at $\mathrm{pH} 8.5)$. The protein suspensions were digested with

Fig. 1. Diagram of experimental design. Timed-pregnant Wistar rats were fed with low protein diet (IUGR) or conventional diet throughout the pregnancy. A subset of dams was killed on D1, and12 kidneys per group were collected, protein extracted, pooled before ITRAQ labeling and subjected to mass spectrometric analysis. Six iTRAQ labels were used: 115,116 and 117 for the C1, C2 and C3; 118,119 and 121 for the I1, I2 and I3 respectively. Bioinformatics analysis (GO, KEGG Pathway, etc) was used to examine367differential expression proteins. Mass spectrometry results were further confirmed by assessing five representative proteins in individual specimens with immunoblotting. Another subset of dams was killed on D7, 3W and12W; kidneys were collected for IHC, WB, and Q-PCR studies.

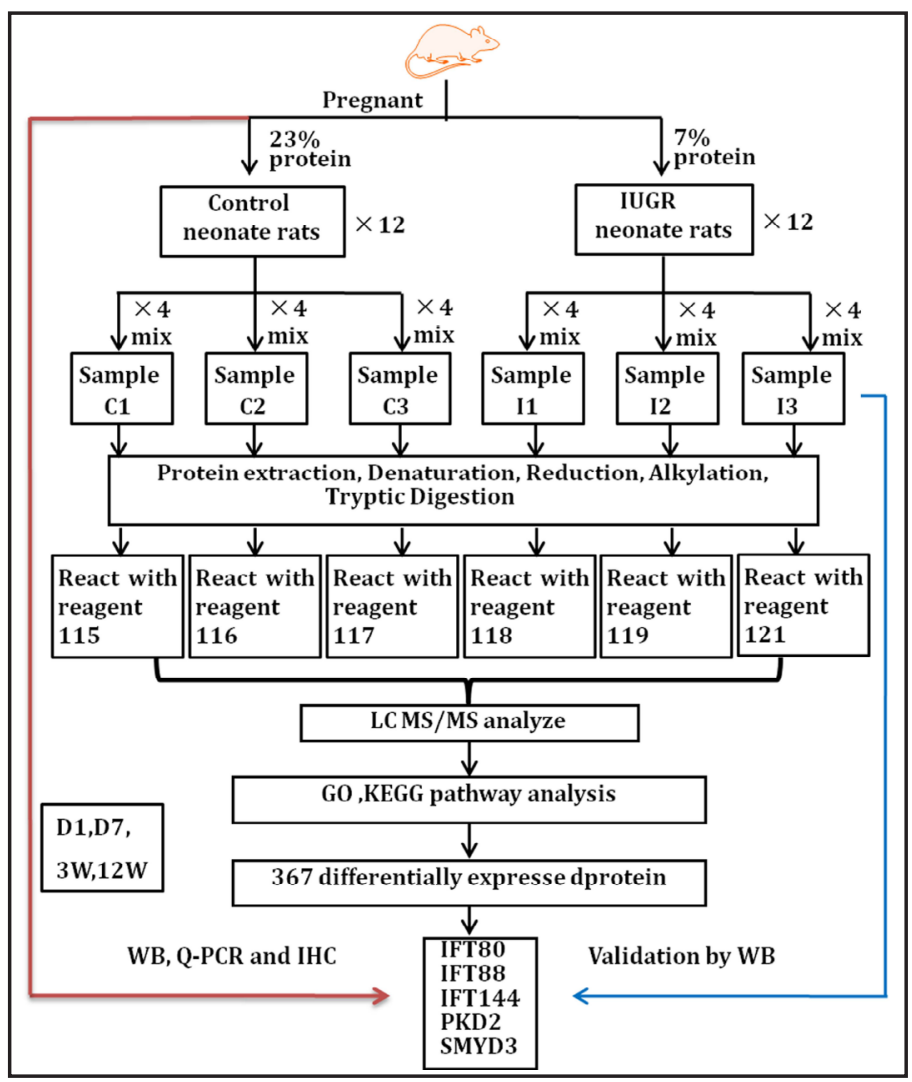




\section{Cellular Physiology Cell Physiol Biochem 2017;44:185-199 \begin{tabular}{l|l|l} 
and BOI: 10.1159/000484626 & $\begin{array}{l}\text { C } 2017 \text { The Author(s). Published by S. Karger AG, Basel } \\
\text { www.karger.com/cpb }\end{array}$ \\
\hline Published online: November 07, 2017
\end{tabular}}

Liu et al.: Proteomics of Neonatal Kidney of IUGR Rats

$3 \mu \mathrm{g}$ of trypsin (Promega Corporation, Madison, WI, USA) in $40 \mu \mathrm{L}$ of DS buffer overnight at $37^{\circ} \mathrm{Cand}$ the resulting peptides were subsequently collected as a filtrate. The peptide content was then measured by UV light spectral density at $280 \mathrm{~nm}$ using an extinction coefficient of $1.1 \mathrm{of} 0.1 \%(\mathrm{~g} / \mathrm{L})$ solution, which was calculated on the basis of the frequency of tyrosine and tryptophan in vertebrate proteins. Each ITRAQ reagent was dissolved in $70 \mu \mathrm{L}$ of ethanol and added to the respective peptide mixture for labeling. The samples were labeled as (CON1)-115, (CON2)-116, (CON3)-117, (IUGR1)-118, (IUGR 2)-119, and (IUGR 3)121. Additionally, the samples were multiplexed and vacuum dried.

\section{Peptide fractionation with strong cation exchange (SCX) chromatography}

iTRAQ-labeled peptides were fractionated by SCX chromatography using the AKTA Purifier system (GE Healthcare, Chalfont St. Giles, UK). The dried peptide mixture was reconstituted and acidified with $2 \mathrm{~mL}$ of buffer A (10 $\mathrm{mM} \mathrm{KH}_{2} \mathrm{PO}_{4}$ in $25 \%$ acetonitrile, $\mathrm{pH}$ 2.7) and loaded onto a PolySULFOETHYL4.6 x $100 \mathrm{~mm}$ column ( $5 \mu \mathrm{m}, 200 \AA \AA$; PolyLCInc, Columbia, MD, USA). The peptides were eluted at a flow rate of $1 \mathrm{~mL} / \mathrm{min}$ with a gradient of $0 \%-10 \%$ buffer $\mathrm{B}\left(500 \mathrm{mM} \mathrm{KCl}, 10 \mathrm{mM} \mathrm{KH}_{2} \mathrm{PO}_{4}\right.$ in $25 \%$ of acetonitrile, $\left.\mathrm{pH} 2.7\right)$ for $2 \mathrm{~min}$, $10-20 \%$ buffer B for $25 \mathrm{~min}, 20 \%-45 \%$ buffer B for $5 \mathrm{~min}$, and $50 \%-100 \%$ buffer B for $5 \mathrm{~min}$. The elution was monitored by absorbance at $214 \mathrm{~nm}$ and fractions were collected every $1 \mathrm{~min}$. The collected fractions (about 30 fractions) were finally combined into 10 pools and desalted on C18 Cartridges (Empore ${ }^{\mathrm{TM}}$ SPE Cartridges C18 (standard density); bed internal diameter, $7 \mathrm{~mm}$; volume, $3 \mathrm{~mL}$; Sigma-Aldrich Corporation). Each fraction was concentrated by vacuum centrifugation and reconstituted in $40 \mu \mathrm{L}$ of $0.1 \%(\mathrm{v} / \mathrm{v})$ trifluoroacetic acid. All samples were stored at $-80^{\circ} \mathrm{C}$ until 2D LC-MS/MS analysis.

\section{LC-electrospray ionization (ESI)-MS/MS analysis by $Q$ Exactive}

Experiments were conducted on a $Q$ Exactive mass spectrometer coupled to anEASY-nLC ${ }^{\mathrm{TM}}$ system (ProxeonBiosystems, now Thermo Fisher Scientific, Waltham, MA, USA). A $10-\mu \mathrm{L}$ aliquot of each fraction was injected for 2D LC-MS/MS analysis. The peptide mixture ( $5 \mu \mathrm{g}$ ) was loaded into a C18-reversed phase column (Thermo Scientific Easy Column, length, $10 \mathrm{~cm}$; inner diameter, $75 \mu \mathrm{m}$; resin, $3 \mu \mathrm{m})$ in buffer A $(0.1 \%$ formic acid) and separated with a linear gradient of buffer B ( $80 \%$ acetonitrile and $0.1 \%$ formic acid) at a flow rate of $250 \mathrm{~nL} / \mathrm{min}$ controlled by IntelliFlow technology over a period of $140 \mathrm{~min}$. A data-dependent top10 method was used to acquire MS data and dynamically choose the most abundant precursor ions from the survey scan $(300-1800 \mathrm{~m} / \mathrm{z})$ for fragmentation by higher-energy collisional dissociation (HCD). The target value was determined based on the predictive automatic gain control technique. The dynamic exclusion duration was $60 \mathrm{~s}$. Survey scans were acquired at a resolution of 70,000 at $\mathrm{m} / \mathrm{z} 200$ and resolution for HCD spectra was set to 17,500 at m/z 200. The normalized collision energy was $30 \mathrm{eV}$ and the under fill ratio, which specifies the minimum percentage of the target value likely to be reached at maximum fill time, was defined as $0.1 \%$. The instrument was run with peptide recognition mode enabled.

Sequence database search and data analysis

MS/MS spectra were searched using the MASCOT engine (Matrix Science, London, UK; version 2.2) embedded into Proteome Discoverer (version 14.0) against a no redundant International Protein Index Arabidopsis sequence database v3.85 (released in September 2011; 39679 sequences) from the European Bioinformatics Institute (http://www.ebi.ac.uk/). The following options were used to identify proteins: peptide mass tolerance $=20 \mathrm{ppm}$; MS $/ \mathrm{MS}$ tolerance $=0.1 \mathrm{Da}$; enzyme $=$ trypsin; missed cleavage $=2$; fixed modification: carbamidomethyl (C), iTRAQ8plex (K), iTRAQ8plex (N-term); and variable modification: oxidation $(\mathrm{M})$, decoy database pattern $=$ reverse.

The MASCOT search results for each SCX elution were further processed using Proteomics Tools software suite (version 3.05), which includes the programs Build Summary, Isobaric Labeling Multiple File Distiller, and Identified Protein iTRAQ Statistic Builder (information can be accessed from the Research Center for Proteome Analysis http://www.proteomics.ac.cn/). The BuildSummary program was used to aggregate protein identifications based on a target-decoy search in shotgun proteomics. All data were reported on the basis of $99 \%$ confidence for protein identification as determined by a false discovery rate (FDR) of $\leq 1 \%$ using the formula FDR $=\mathrm{N}($ decoy $) * 2 /((\mathrm{N}$ (decoy) $+\mathrm{N}($ target $))$.

The programs Isobaric Labeling Multiple File Distiller and Identified Protein iTRAQ Statistic Builder were used to calculate the ratios of proteins, in which Sample REF was used as reference on the base of the weighted average of the intensity of reporter ions of each identified peptide. The final protein ratios were then normalized by the median average protein ratio for an unequal mix of the different labeled samples. 


\section{Cellular Physiology Cell Physiol Biochem 2017;44:185-199

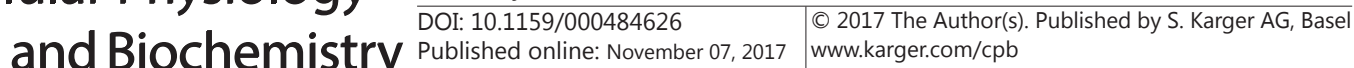

Liu et al.: Proteomics of Neonatal Kidney of IUGR Rats

\section{Bioinformation analysis}

The sequence data of 367 differentially expressed proteins (DEPs) were in batches retrieved from the UniProtKB database (Release 2014_02) in FASTA format. The retrieved sequences were locally searched against the SwissProt database (mammals) using the Basic Local Alignment Search Tool (ncbi-blast-2.2.28+win32.exe) to find homologue sequences from which the functional annotation can be transferred to the studied sequences. In this work, the top 10 BLAST hits with E-value less than $1 \mathrm{e}-3$ for each query sequence were retrieved and loaded into Blast2GO [27] (version 2.7.2) for Gene Ontology (G0) [28] mapping and annotation. The studied proteins were blasted against the Kyoto Encyclopedia of Genes and Genomes (KEGG) GENES (rats) database to retrieve KEGG orthologies (KOs)that were subsequently mapped to the respective KEGG pathways [29].Global protein expression patterns in neonatal rat kidneys were illustrated using K-means clustering in conjunction with a heatmap and volcano plot (http://www.omicshare.com/ tools/Home/Soft) [30].Functional classifications of the identified proteins were generated by searching against the IntAct database (Rodentia) with Cytoscape and String database, an online tool.

\section{Protein assay and immunoblotting}

Total proteins were extracted with SDT buffer as mentioned above. Histones were extracted from kidney tissues using the EpiQuik ${ }^{\mathrm{TM}}$ Total Histone Extraction Kit (EpiGentek Group Inc., Farmingdale, NY, USA) and quantified with the BCA Protein Quantification Kit (Pierce Biotechnology, Waltham, MA, USA). Five proteins were chosen for validation (Table 1). Proteins were separated by electrophoresis on $6 \%-$ $12 \%$ agarose gels, depending on the molecular weights of the target proteins, using the Mini Protean III system (Bio-Rad Laboratories, Hercules, CA, USA) and transferred to polyvinylidene fluoride membranes (EMD Millipore Corporation, Billerica, MA, USA) as described by Towbin et al. [31]. The filter was then blocked with $5 \%$ nonfat milk for $2 \mathrm{~h}$ at room temperature. After incubation with primary antibodies at $4^{\circ} \mathrm{C}$ overnight, the blot was then incubated with horseradish peroxidase (HRP)-conjugated secondary antibodies for $2 \mathrm{~h}$ at room temperature and imaged using Immobilon Chemiluminesent HRP substrate (EMD Millipore Corporation) and a ChemiDoc XRS Imaging System (Bio-Rad Laboratories). Band densities were analyzed using Gel-analyzer software. Rabbit polyclonal antibodies for intraflagellar transport (IFT) 80, IFT88, IFT144, PKD2, and SMYD3 (25230-1-AP, 13967-1-AP, 13647-1-AP, 19126-1-AP, 12011-1-AP; Proteintech Group, Inc., Chicago, IL, USA) and mouse monoclonal $\beta$-actin antibody (60008-1-Ig; Proteintech Group, Inc.) were used as primary antibodies. The relative expression of the target protein is reported as the percentage of the optical density (OD) of the target protein, adjusted with the corresponding OD of $\beta$-actin. The levels of d H3K4Me3 (A2357, ABclonal, Inc., Woburn, MA, USA) were determined by western blot analysis with H3 (E1A6359-1; EnoGene Biotech Co. Ltd., Nanjing, China) as a loading control. Experiments were conducted in triplicate for each antibody.

\section{Immunohistochemical (IHC) analysis}

The neonatal kidneys were harvested, fixed, and embedded in paraffin. IHC staining was performed on 3- $\mu \mathrm{m}$ sections using standard techniques. In brief, after antigen retrieval, blocking for endogenous

Table 1. Proteins chosen for WB validation. (C: control; I: IUGR; Peptide: the number of peptides identified by LC-MS/ MS)

\begin{tabular}{|c|c|c|c|c|c|c|}
\hline $\begin{array}{l}\text { Protein } \\
\text { ID }\end{array}$ & $\begin{array}{l}\text { Gene } \\
\text { Symbol }\end{array}$ & Proteins & $\begin{array}{l}\text { Unique } \\
\text { Peptides }\end{array}$ & $\begin{array}{l}\text { Average } \\
\text { iTRAQ } \\
\text { ratio } \\
(\mathrm{I} / \mathrm{C})\end{array}$ & P-value & Main function \\
\hline Q66HB3 & $\begin{array}{l}\text { intraflagellar } \\
\text { transport80 }\end{array}$ & 1 & 1 & 1.51 & 0.011 & $\begin{array}{l}\text { Component of the IFT complex B, } \\
\text { which is essential for the } \\
\text { development and maintenance of } \\
\text { motile and sensory cilia }\end{array}$ \\
\hline D4ACI9 & $\begin{array}{l}\text { intraflagellar } \\
\text { transport88 }\end{array}$ & 1 & 1 & 1.436 & 0.007 & $\begin{array}{l}\text { Component of the IFT complex B, } \\
\text { involved in primary cilium } \\
\text { biogenesis. Also involved in } \\
\text { autophagy }\end{array}$ \\
\hline F1LV01 & $\begin{array}{l}\text { intraflagellar } \\
\text { transport144 }\end{array}$ & 1 & 1 & 1.226 & 0.013 & $\begin{array}{l}\text { Component of the IFT complex A, } \\
\text { involved in retrograde movement } \\
\text { of cargo in the cilium. }\end{array}$ \\
\hline Q4V8B9 & $\begin{array}{l}\text { SET and } \\
\text { MYND domain } \\
\text { containing } 3\end{array}$ & 23 & 2 & 1.485 & 0.026 & $\begin{array}{l}\text { Histone methyltransferase. } \\
\text { Specifically methylates H3K4, } \\
\text { inducing di- and tri-methylation, } \\
\text { but not monomethylating. Also } \\
\text { methylates H4K5. Plays an } \\
\text { important role in transcriptional } \\
\text { activation as a member of an RNA } \\
\text { polymerase complex }\end{array}$ \\
\hline
\end{tabular}


Liu et al.: Proteomics of Neonatal Kidney of IUGR Rats

peroxidase, and non-specific binding, the sections were incubated with primary antibodies overnight at $4^{\circ} \mathrm{C}$ in a humidified chamber. Afterwards, the biotinylated secondary antibody (Beyotime, China) was applied for $30 \mathrm{~min}$ at room temperature. The reaction products were visualized using $3,3^{\prime}$-diaminobenzidine tetrahydrochloride and the slides were counterstained with hematoxylin. The primary antibodies were the same as those used for western blot analysis. Imaging under high magnification (400x) was performed using an ECLIPSE Ti microscope (Nikon Corporation, Tokyo, Japan). All images were quantified base on the integrated optical density (IOD) with Image Pro Plus software (ver. 6.0; Media Cybernetics, Inc., Rockville, MD, USA).

\section{RNA extraction and RT-PCR}

RNA was extracted from snap-frozen kidney tissues using TRIzol reagent (Invitrogen Corporation, Carlsbad, CA, USA) according to the manufacturer's protocol. The concentration and purity of RNA was determined in duplicate using a spectrophotometer (NanoVue; GE Healthcare, Buckinghamshire, England). For SYBR-based real-time PCR, cDNA synthesis was performed using the M-MLV First Strand kit (C28025032; Invitrogen Corporation) in a final volume of $40 \mu \mathrm{L}$ following the manufacturer's instructions. To minimize variation in the reverse transcription reaction, all RNA samples from a single experimental setup were reverse transcribed simultaneously. A set of candidate HKGs (hypoxanthine guanine phosphoribosyl transferase 1 (HPRT1), $\beta$-actin, $\alpha$-tubulin, glyceraldehyde-3-phosphate-dehydrogenase (GADPH), RPLP1 and UBC) were chosen to be assessed in the kidney tissues of neonatal rat in both groups $(n=8)$. The expression stability of these genes was analyzed using BestKeeper software, an Excel-based tool [32]. Among the six internal reference genes, $\beta$-actin shows the most stable expression (with "coeff. of corr. [r]" $=0.94$ and "std dev $[ \pm \mathrm{CP}]<1 ")$ ) between IUGR and the control group (Fig. 2). For this reason, we chose

Fig. 2. Expression stability of housekeeping genes in neonatal rat kidney tissues analyzed with the BestKeeper software. (A, B) Genes with the highest $[\mathrm{r}]$ values have the most stable expression( $\mathrm{n}=$ 8 per group), (C) Specificity of PCR products were confirmed by visualized on $2 \%$ agarose gels.

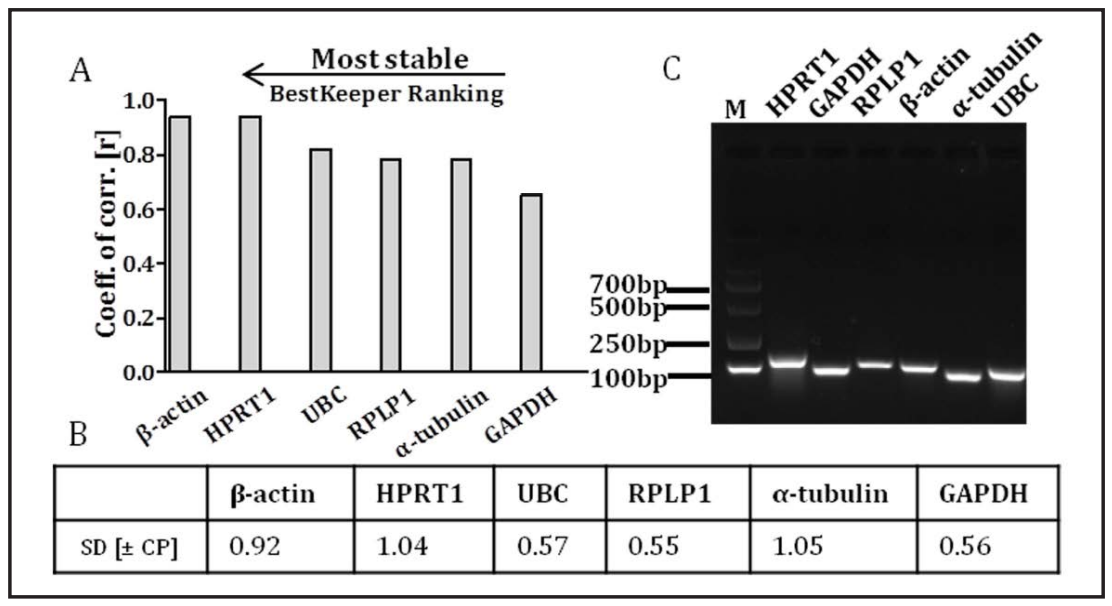

Table 2. Primers for quantitative real-time reverse transcription polymerase chain reaction

\begin{tabular}{|c|c|c|c|c|c|}
\hline Gene name & $\begin{array}{l}\text { Accession } \\
\text { Number }\end{array}$ & Primer Sequences & Position & Size (bp) & Annealing temp $\left({ }^{\circ} \mathrm{C}\right)$ \\
\hline \multirow[t]{2}{*}{ IFT80 } & NM_001013911 & F: 5- AACATCCAGGAGGCTGAAAC3 & $2145-2164$ & 96 & 60 \\
\hline & & R: 5- CAGTGCCCTTTCCCAGTTAT-3 & $2221-2240$ & & \\
\hline \multirow[t]{2}{*}{ IFT88 } & NM_001107266 & F: 5- TTCAGCAAGCAGTGAGAACC-3 & $182-201$ & 112 & 60 \\
\hline & & R: 5-AGGGATGTCTTGGACCCATA-3 & $274-293$ & & \\
\hline \multirow[t]{2}{*}{ IFT144 } & NM_001191679 & F: 5-ATGAGGCCGGAATACCGCAA -3 & $3710-3729$ & 121 & 62 \\
\hline & & R: 5-ACTGGCAGAAGGGACATGGG-3 & $3811-3830$ & & \\
\hline \multirow[t]{2}{*}{ PKD2 } & NM_001191934 & F: 5-AAGCTGACAACCGGAGCTTT -3 & $899-918$ & 198 & 60 \\
\hline & & R:5- AGATCCACGCAGTTCCGTTC-3 & $1077-1096$ & & \\
\hline \multirow[t]{2}{*}{$\beta$-actin } & NM_031144 & F: 5- AGTCCCTCACCCTCCCAAAAG-3 & $3475-3495$ & 96 & 60 \\
\hline & & R: 5- AAGCAATGCTGTCACCTTCCC-3 & $3550-3570$ & & \\
\hline \multirow[t]{2}{*}{$\alpha$-tubulin } & XM_017603502 & F: 5-CCATGCGTGAGTGTATCTCC-3 & $349-368$ & 75 & 60 \\
\hline & & R: 5-GTGCCAGTGCGAACTTCATC-3 & $404-423$ & & \\
\hline \multirow[t]{2}{*}{ RPLP1 } & NM_001007604 & F: 5- CTGCATCTACTCCGCCCTCA-3 & $135-154$ & 116 & 60 \\
\hline & & R: 5- ACAAGCCAGGCCAGAAAGGT-3 & $231-250$ & & \\
\hline \multirow[t]{2}{*}{ HPRT1 } & NM_012583 & F: 5- CTCATGGACTGATTATGGACAGGAC-3 & 79-203 & 123 & 60 \\
\hline & & R:5-GCAGGTCAGCAAAGAACTTATAGCC-3 & $277-301$ & & \\
\hline \multirow[t]{2}{*}{$G A P D H$} & NM_017008 & F: 5- ATGACTCTACCCACGGCAAG-3 & $215-234$ & 86 & 60 \\
\hline & & R:5- GGAAGATGGTGATGGGTTTC-3 & $282-301$ & & \\
\hline \multirow[t]{2}{*}{$U B C$} & NM_017314 & F: 5- TCGTACCTTTCTCACCACAGTATCTAG-3 & $2407-2432$ & 81 & 60 \\
\hline & & R: 5-GAAAACTAAGACACCTCCCCATCA-3 & $2464-2487$ & & \\
\hline
\end{tabular}


$\beta$-actin as the reference gene. Real time PCR was performed on LightCycle480 (Roche, Basel, Switzerland) in triplicate. cDNA was added to the reaction mixture containing the specific primer pairs (Table 2), and diluted with LightCycler ${ }^{8} 480$ SYBR Green I Master Mix (Roche, Mannheim, Germany). Specificity of the PCR products was confirmed by analysis of the dissociation curve. In addition, the amplicons' expected size and the absence of nonspecific products were confirmed by analysis of the PCR products on $2 \%$ agarose gels, subsequently stained with ethidium bromide and visualized under UV light. The relative mRNA levels were calculated using the 2- $\Delta \Delta \mathrm{Ct}$ method after normalization with $\beta$-actin as a housekeeping gene. All Q-PCR data for RNA expression analysis were calculated using the $2-\Delta \Delta \mathrm{Ct}$ method.

\section{Statistical analysis}

Data are expressed as means \pm SEM. Statistical analyses were performed with the GraphPad Software (San Diego, CA, USA).The Student's unpaired t-test determined statistical significance. Two-sided $\mathrm{p}<0.05$ was considered significant.

\section{Results}

Global profiling of proteins in neonatal rat kidney

In this work, 24 neonates underwent high accuracy LC-MS/MS iTRAQ analysis combined with SCX, with 12 rats per experimental group. Using untargeted proteomic analysis, a total of 31,868 peptides matching 5,674 proteins ( $\geq$ one or more unique peptides with an FDR less than $1 \%$ ) were identified.

\section{Identification of significant DEPS}

Fold changes of proteins were determined by the ratios of the iTRAQ reporter ions between normal and IUGR kidneys. Using a threshold of 1.2 -fold change and a P value $\leq$ 0.05 (this level of fold change was chosen as it can be more easily validated using other biochemical / immunological methods such as quantitative western blotting), 367 proteins

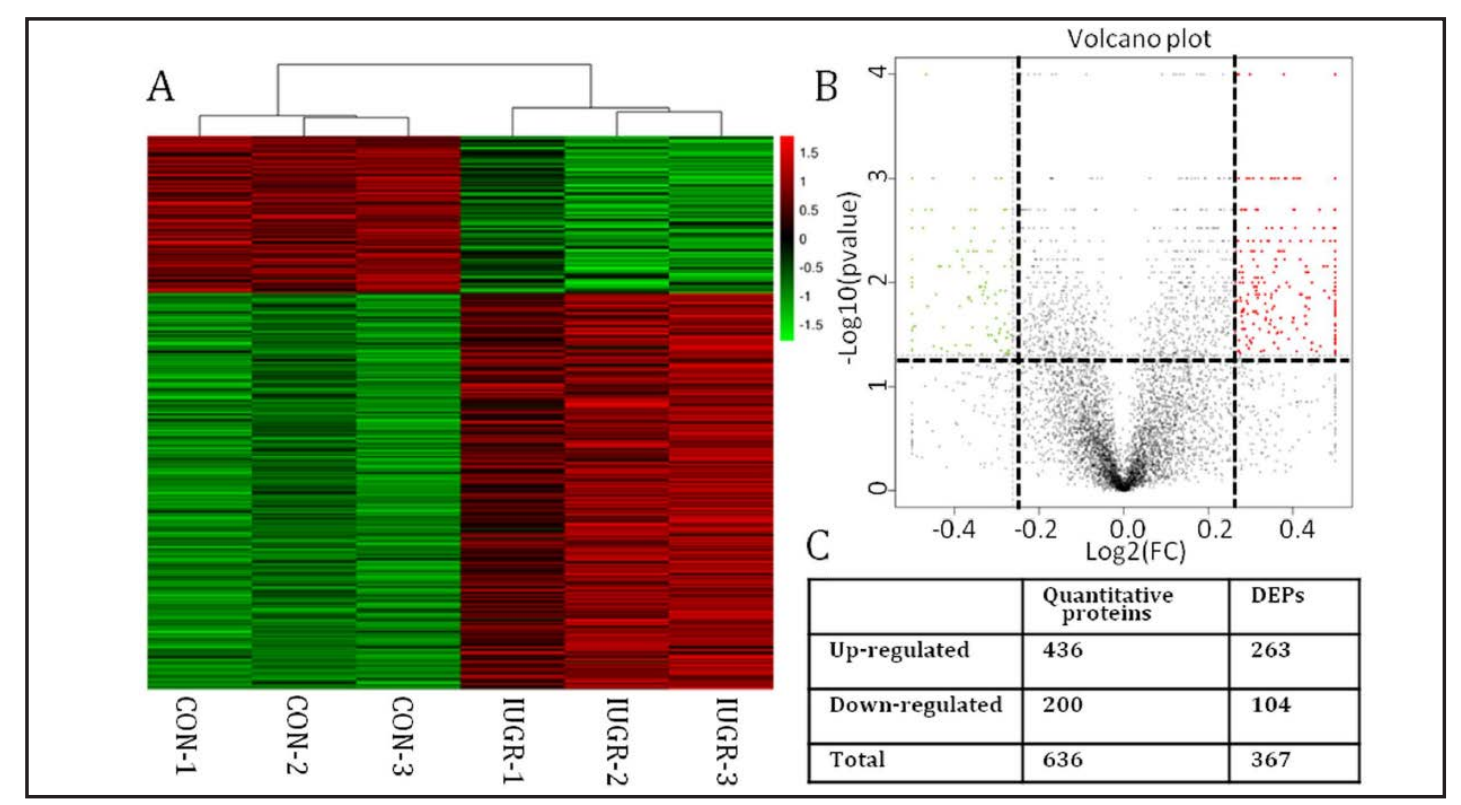

Fig. 3. Global protein expression patterns in neonatal rat kidneys. (A) K-means clustering representation of total 367 DEP profiles. The magnitude of the percentage is represented by a color scale (top right) going from low (green) to high (red). (B) Volcano plots showing the distribution of significance and fold change of identified proteins in the IUGR/CON comparison. All proteins were plotted with fold change on the x-axis and $p$-value on the y-axis. Vertical dotted lines mark a fold change of $\pm 120 \%$ and the horizontal dotted line marks $P=0.05$. (C) The number of DEPs. 
Fig. 4. GO annotation and functional classification of DEPs: Geneontology terms for subcellular location distribution (A), molecular functions (B), and biological process (C).

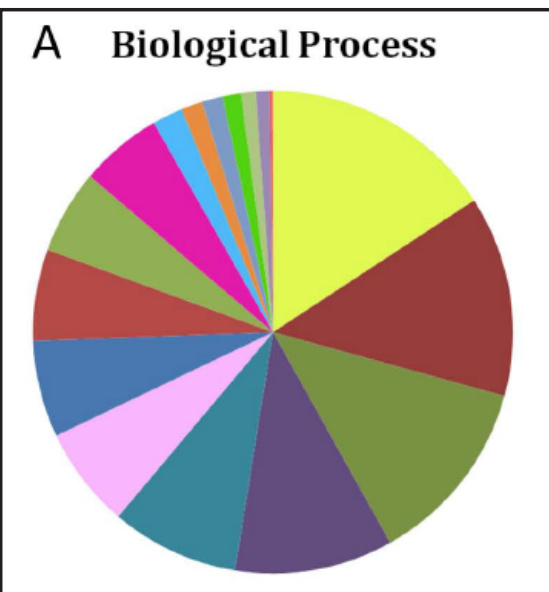

\section{B Molecular Function}

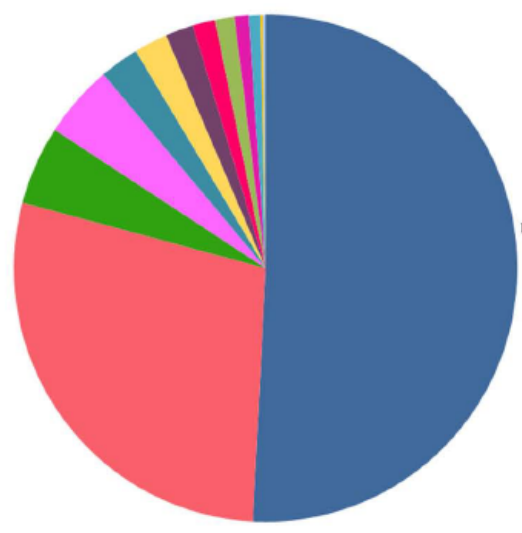

C Cellular Component

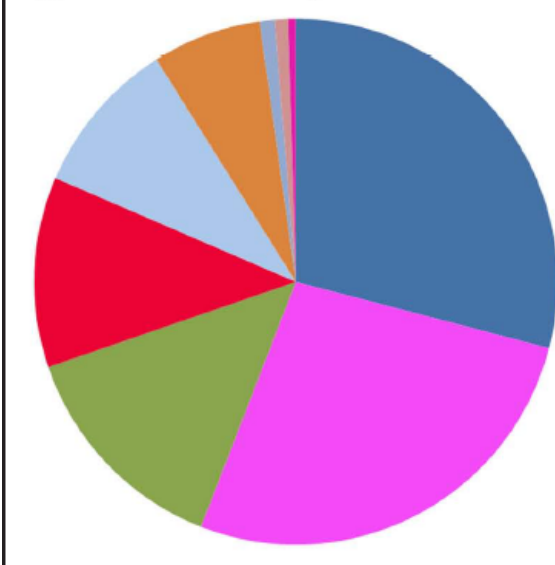

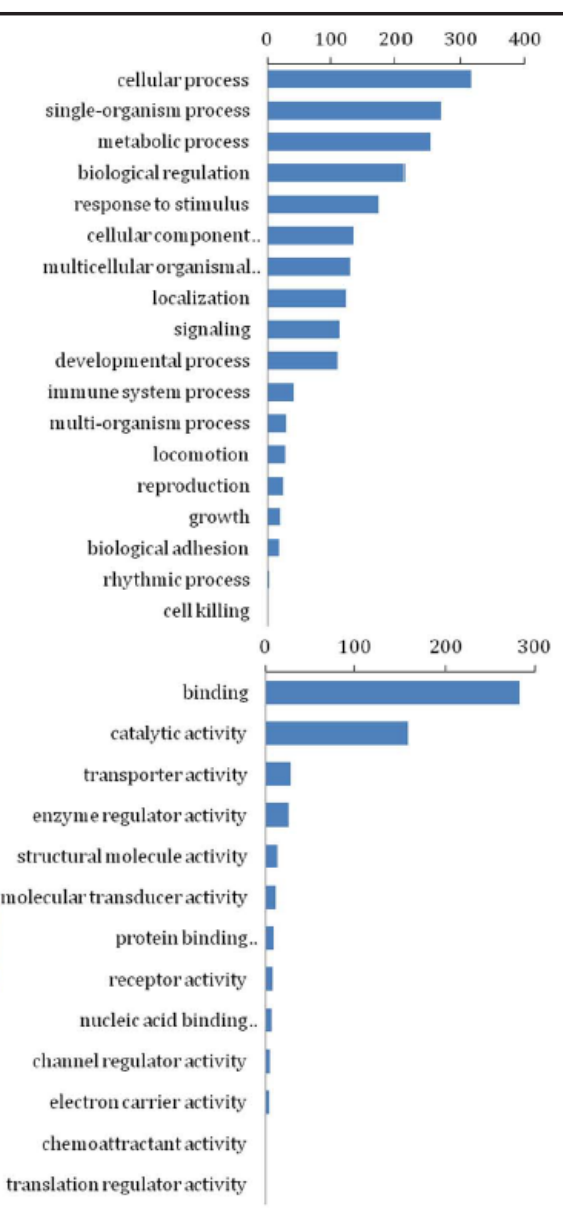

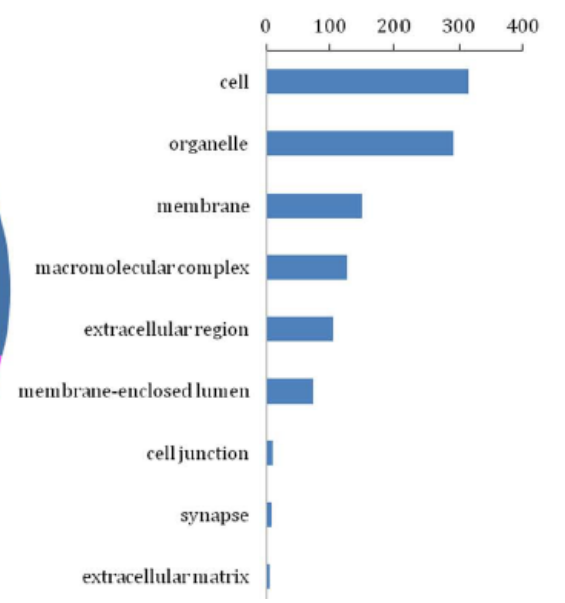

(263 up-regulated and 104 down-regulated) displayed significant differential expression between IUGR neonatal kidneys and age-matched control. We also identified significance and magnitude of change in expression of DEPs between two groups, using K-means clustering heatmaps and volcano plot (Fig. 3A, B).

Bioinformatics analysis of DEPs

To gain insights into the biological changes, the DEPs identified by MS were subsequently classified by bioinformatics analysis. A total of 363 proteins differentially expressed in SPTP were annotated to 4322 GO function entries. Second-level GO terms were applied to 
classify proteins in terms of their involvement in three main categories (cellular component, molecular function and biological process) and each protein was assigned at least one term. For these identified DEPs, more than 86\% (315proteins) were annotated as belonging to the cell compartment, and the other two main categories of these proteins were the organelle (291 proteins) compartments and macromolecular complex (120 proteins)(Fig. 4A). According to the molecular function classifications, most of the DEPs are associated with protein binding (173 proteins), catalytic activity (133 proteins), enzyme regulator activity (23 proteins) and transporter activity (22 proteins), (Fig. 4B). The top three biological processes identified were cellular process (278 proteins), metabolic process (222 proteins), and single-organism process (204 proteins) (Fig. 4C). In addition, the DEPs were analyzed with the KAAS (KEGG Automatic Annotation Server) to identify pathways that would be potentially affected in IUGR. The top five pathways identified were the Huntington's disease (11 proteins), Oxidative phosphorylation (9 proteins), Parkinson's disease ( 9 proteins), Epstein-Barr virus infection (9 proteins), and Purine metabolism (8 proteins), (Table 3).

\section{Primary ciliacomponent proteins investigation}

ITRAQ data showed there were multiple primary cilia proteins with differential expression, including IFT80, IFT88, and WDR19 (IFT144). Protein-protein interactions, including direct (physical) as well as indirect (functional) associations, were confirmed by the STRING database (Fig. $5 \mathrm{~A}$ ). In order to confirm the results from the 2D LC-MS/MS experiment, western blotting was used to quantify the expression of IFT80, IFT88, and WDR19 (IFT144). These IFT family proteins were chosen as they localize to the primary cilia, and primary cilia have previously been implicated in kidney development. We also investigated the expression of PKD2, the dominant gene for polycystic kidney disease (PKD),

Table 3. List of main KEGG pathways

\begin{tabular}{lllll}
\hline Term & Map name & Number & Up-regulated proteins & Down-regulated proteins: \\
\hline ko05016 & Huntington's disease & 11 & D3ZQI0 M0RBH0 Q06647 A9UMV7 D4A898 P15337 D3ZF13 P51111 D3ZFQ8 P00406 & Q8SE25 \\
k000190 & Oxidative phosphorylation & 9 & D3ZAF6 Q06647 A9UMV7 D3ZF13 Q8HN20 M0RBN8 D3ZFQ8 P00406 & Q8SEZ5 \\
ko05012 & Parkinson's disease & 9 & B0BNB9 Q06647 A9UMV7 D3ZF13 Q8HN20 D3ZFQ8 P00406 & Q8SEZ5 P10824 \\
k005169 & Epstein-Barr virus infection & 9 & M0RCB1 D3ZQI0 P19139 M0RBH0 D4A898 D3ZV30 M0R8M9 Q5XIL3 G3V9W2 & \\
k000230 & Purine metabolism & 8 & D3ZQI0 M0RBH0 D3ZV30 P36972 G3V8M1 Q5XIL3 089044 Q642A5 & M0RA26 Q0QEW8 P62282 \\
k000240 & Pyrimidine metabolism & 8 & D3ZQI0 M0RBH0 D3ZV30 G3V8M1 Q5XIL3 Q4KM73 089044 Q642A5 & Q8SEZ5 P02650 \\
k003010 & Ribosome & 8 & D3ZX69 P62864 P62275 P19944 P62986 & Q6AYL5 B1WC40 \\
k005010 & Alzheimer's disease & 8 & Q06647 A9UMV7 D3ZF13 M0R660 D3ZFQ8 P00406 & P51639 P29975 Q04679 Q99PE7 P07687 \\
k003040 & Spliceosome & 7 & F1M2S4 D3ZGL5 M0RCB1 M0R8M9 D3ZSP1 & \\
k004976 & Bile secretion & 7 & Q8R4H8 P11167 &
\end{tabular}

Fig. 5. The STRING network and western blotting analysis of primary cilia component proteins in the kidney of rat neonates. (A) The STRING network of primary cilia componentswith altered expression. Colored lines between the proteins indicate the various types of interaction evidence. Protein nodes which are enlarged indicate the availability of 3D protein structure information. (B, C) Representative immunoblotting and
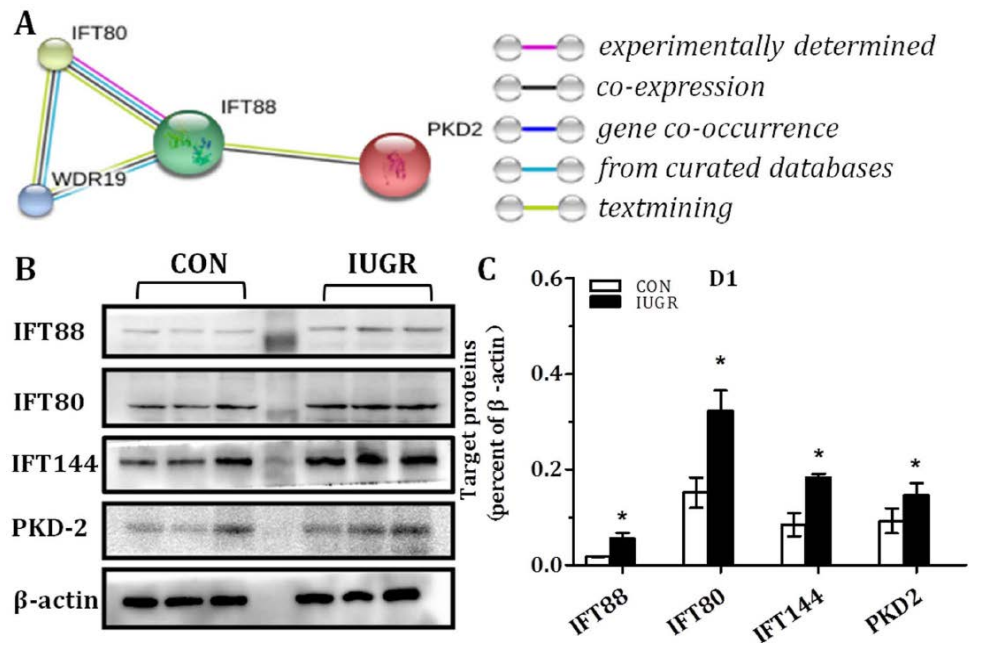
densitometric analysis of primary cilia component proteins expression in the neonatal kidney. Results were normalized relative to the expression of $\beta$-actin ( $n=6$ per group, ${ }^{*} P<0.05$, vs. control). Western blot analysis showed increased levels of IFT family proteins and PKD2 in the IUGR rat neonates. 
Fig. 6. IHC analysis of primary cilia component proteinsin the kidney of neonate rats. (A-F) Representative photomicrographs of IHC-staining for IFT80, IFT88, and PKD2 in the kidney sections from Con (Left panel) and IUGR (right panel). (Original magnification $\times 400$, scale bar $=$ $100 \mu \mathrm{m})$. IFT80 and IFT88 were mainly expressed in tubule cells and a weak staining was also found in glomeruli cells (black arrowhead). While PKD2 protein mainly localized in the tubule cells, not detected in glomeruli cells. (G) IHC staining was quantified base on IOD with Image Pro Plus software. ( $\mathrm{n}=3$ per group, ${ }^{*} P<0.05$, vs. control).

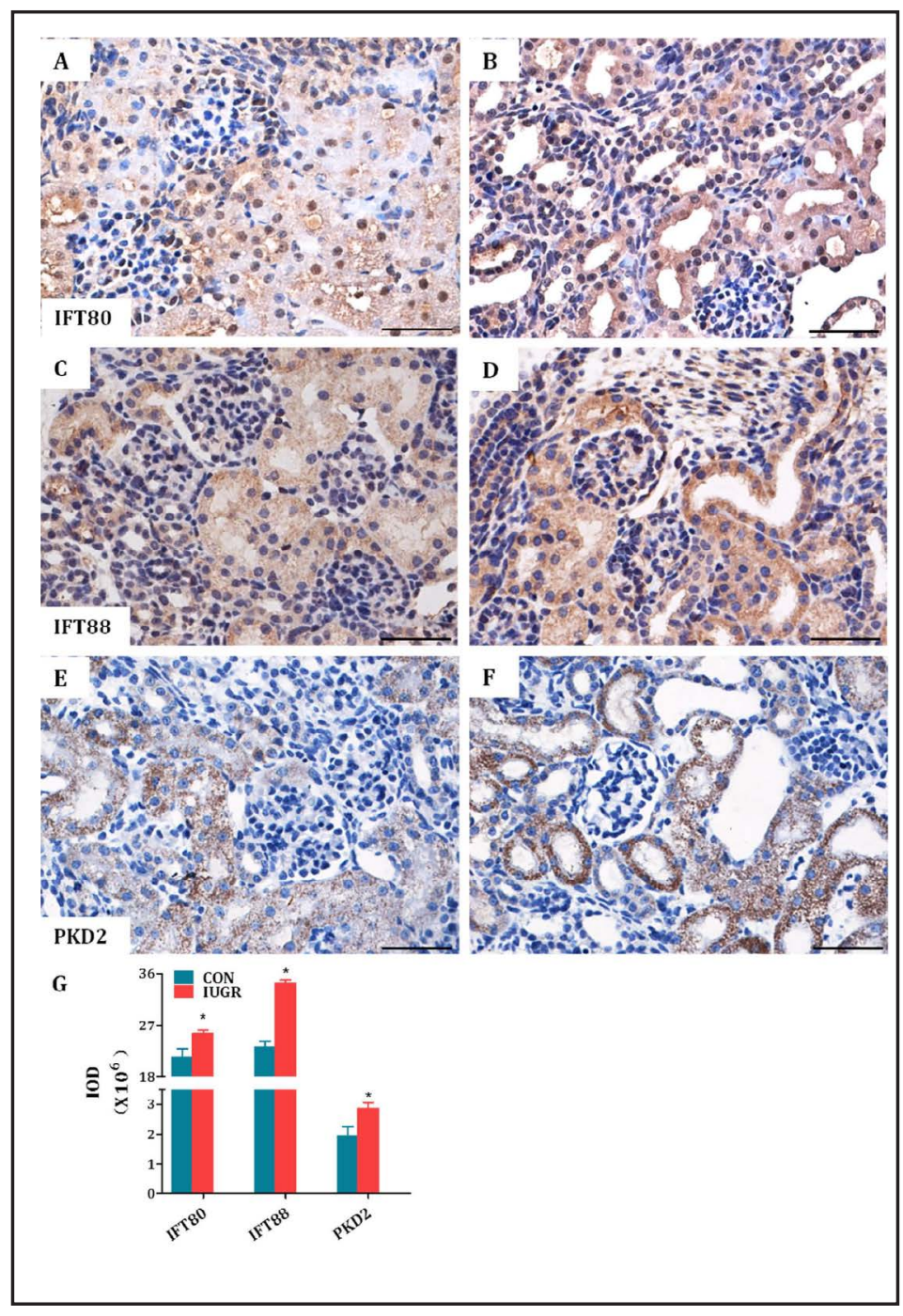

which has been found to localize to the primary cilia, although it was not detected by iTRAQ analysis. Protein levels of primary cilia components were quantified by western blotting with $\beta$-actin as the housekeeping protein. Maternal protein restriction and subsequent IUGR significantly increased kidney primary cilia component levels compared with control, and confirmed the iTRAQ data (Fig. 5B, C).We further investigated protein distribution by IHC in the kidney. By IHC, IFT80 and IFT88 share the same localization pattern, with high staining Intensity in tubule cells and low Intensity in glomeruli cells (6A-D), While PKD2 protein mainly localized in the tubule cells, they were not detected in glomeruli cells (Fig. 6E, F). Binding specificity was confirmed by replacing the antibodies with nonimmune rabbit IgG (not supplied). No difference was observed in the localization pattern of primary cilia factors in normal and IUGR kidneys; however, all three factors appear to be higher expressed in IUGR kidneys, evidenced by IOD analysis (Fig. 6G).

\section{Primary cilia components mRNAs in kidney during development}

To explore the expression changes of the DEPs occurred at transcription stage or translation stage, Q-PCR was applied to detect the mRNA level of five candidate proteins in the kidney at different stages of development. Similar to the protein data, we observed an increase in IFT80 and IFT144 mRNA levelsat D1, whereas it restored to normal at D7 (Fig. 7B, C). IFT88 mRNA increased significantly at 3W (juvenile stage) and 12W (adult stage) compared to same-aged control (Fig. 7A). PKD2 mRNA in neonatal kidney of IUGR 
Fig. 7. Temporal expressions of primary cilia component mRNA in IUGR kidney. (A-D) IFT88, IFT80, IFT144 and PKD2 mRNA levels in IUGR kidneys for different time points were determinated by quantitative RT-PCR with $\beta$-actin as the housekeeping genes. (E) Specificity of PCR products were confirmed by visualized on $2 \%$ agarose gels. Results were normalized relative to the same-aged control $(\mathrm{n}=$ 8 per group, $* P<0.05$, vs. control at the same time point).
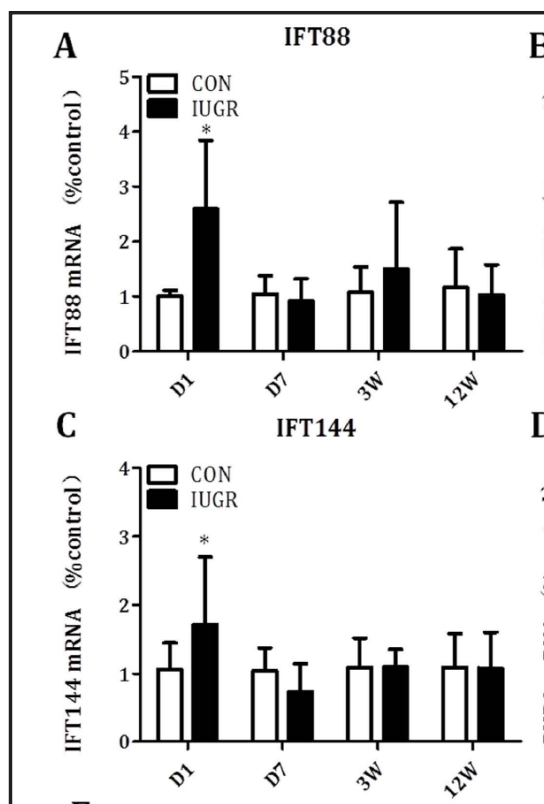

E
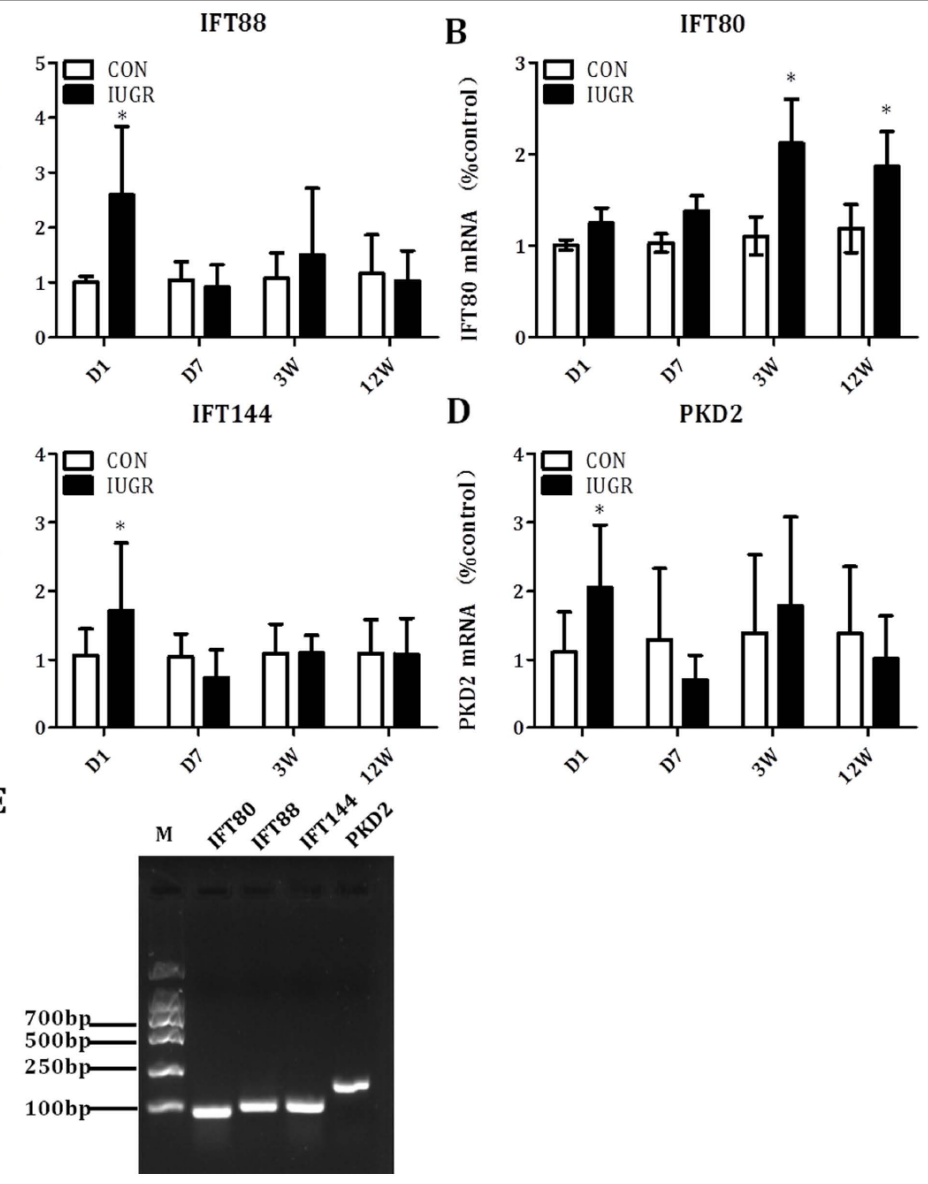

Fig. 8. Effect of IUGR on histone modification and enzyme in the neonatal kidneys. (A) Western blot analysis showed enhanced levels of kidney SMYD3 in the IUGR neonates, with $\beta$-actin as a loading control. (B) H3K$4 \mathrm{me} 3$ was also remarkably increased in IUGR groups,
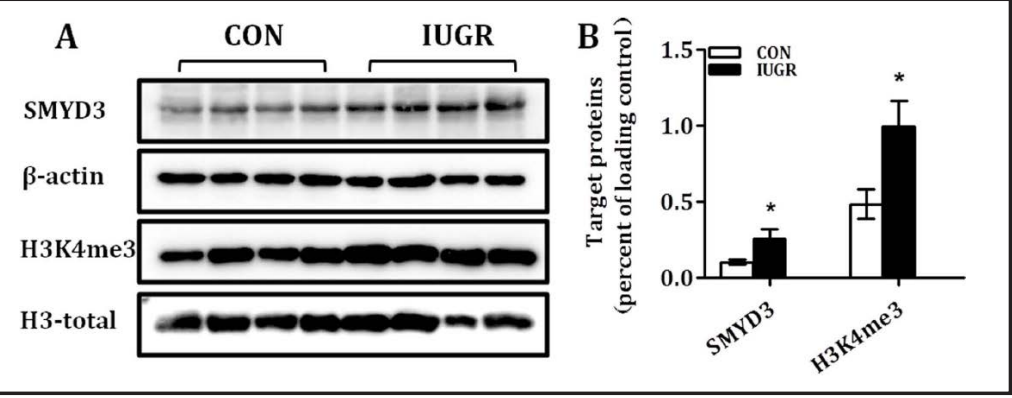
with H3 as a loading control. Results were normalized relative to the same-aged control $(\mathrm{n}=6$ per group, $* P<0.05$, vs.control).

was significantly higher than in the control group, but soon returned to normal level and maintained to adulthood. (Fig. 7D).

\section{Epigenetic modulating factors investigation}

iTRAQ data showed that SMYD3, a methyltransferase for H3K4 was up-regulated in IUGR neonatal kidneys. In western blot analysis, SMYD3 protein was markedly increased, consistent with the iTRAQ data. Accordingly, H3K4me3 level was remarkably enhanced in IUGR neonatal kidneys (Fig. 8). 


\section{Cellular Physiology Cell Physiol Biochem 2017;44:185-199 \begin{tabular}{l|l|l} 
and Biochemistry Published online: November 07, 2017 & $\begin{array}{l}\text { (c) 2017 The Author(s). Published by S. Karger AG, Basel } \\
\text { www.karger.com/cpb }\end{array}$ \\
\hline
\end{tabular}}

Liu et al.: Proteomics of Neonatal Kidney of IUGR Rats

\section{Discussion}

IUGR indicates that the fetus has failed to achieve its full growth potential. Decreased fetal growth rates reflect a temporary adaptation to the adverse intrauterine environment, but may lead to malfunction of organ systems later in life. Epidemiological studies have demonstrated that adverse intrauterine environments during fetal life may lead to diseases in adulthood, such as type 2 diabetes, hypertension and chronic kidney disease. Experimental models also provided data supporting a link between adverse intrauterine environment and adult disease. Both uteroplacental insufficiency and calorie restriction in pregnant rats led to high blood pressure in their adult offspring [33]. We have previously shown that a low maternal protein diet during pregnancy results in lower kidney index, glomeruli number and decreased glomerular filtration rate in IUGR offspring, with an increased incidence of hypertension [8]. Although the link is established, the underlying mechanisms are not clearly demonstrated.

In this paper, we applied the sample-pooling comparative proteomics method to investigate the differences in kidney proteome profiles between neonatal IUGR rats and normal rats. In addition, we conducted an in-depth study on the space-time changes of DEPs in IUGR offspring, with the goal of elucidating the kidney injury mechanisms underlying IUGR. We identified a total of 367 proteins that showed significant differences in expression profile. Functional classification of these differential proteins showed that they play important roles in oxidative phosphorylation, purine metabolism, pyrimidine metabolism, RNA small body, spliceosome and IFT. These DEPs might participate in postnatal kidney disease and subsequent hypertension in IUGR rats.

IFT family proteins displayed significant differential expression in IUGR neonatal kidneys. These proteins, including IFT80, IFT88and IFT144, belong to the primary cilium complex $A(144)$ and $B(80,88)$ module [34]. The primary cilium, a slim microtubule-based organelle that projects from the surface of vertebrate cells, has been located on almost every mammalian cell type [33]. Cilia are essential for certain developmental signaling pathways and mechanosensory functions, like detecting flow or mechanical movement and inducing an influx of $\mathrm{Ca}^{2+}[24]$. Numerous human diseases and developmental abnormalities have been linked to defects in ciliary structure or in cilia-localized proteins, including polycystic kidney disease (PKD), hepatic and pancreatic defects, obesity and skeletal patterning abnormalities. [32, 35].Sarah Goetz defined the cilia as a signaling center during vertebrate development for its role in modulating Wnt and Hedgehog (Hh) signal transduction [36]. In kidney, cilia were showed to be modulators of canonical and non-canonical Wnt signaling activities involving tubular epithelial cells. Downregulation of essential ciliogenesis genes, including Ift88 in murine cells, lead to elevated nuclear $\beta$-catenin accumulation and enhanced transcriptional activity of canonical Wnt target genes [37]. Moreover, IFT88 homolog was shown to be a regulator of the cell cycle in non-ciliated, tissue culture cells and to play a role in spindle orientation [38]. The role of cilia in kidney development and injury is complex and it has not been studied in depth, to date. Thus, additional experiments that examine Wnt or Hh signaling in IUGR offspring will be required to elucidate the effect of IFT family proteins on fetal kidney development.

Epigenetic regulation of gene expression is important for integrating signaling input and transcriptional output during organ development. However, to date, little is known about how malnutrition intrauterine affects the epigenetic modification of embryo kidneys in IUGR models. Histone lysine methylation has been widely accepted as a key epigenetic modification. SMYD3 is a methyltransferase for both H3K4 and H4K5 [39, 40]. It is of vital importance for cardiac and skeletal muscle development during zebrafish embryogenesis [41]. H3K4me3 plays a crucial role in regulating mammalian gene expression and embryonic development $[42,43]$, evidenced by the fact that it occupies as many as $75 \%$ of all human gene promoters in several cell types (e.g., ES cells) [44].

The present study first showed that SMYD3 levels were enhanced in IUGR neonatal kidneys, which might methylate H3K4 in kidneys. Increased H3K4me3 levels are positively 


\section{Cellular Physiology Cell Physiol Biochem 2017;44:185-199 \begin{tabular}{l|l|l} 
and Biochemistry $1011159 / 000484626$ & $\begin{array}{l}\text { C } 2017 \text { The Author(s). Published by S. Karger AG, Basel } \\
\text { www.karger.com/cpb }\end{array}$
\end{tabular} \\ Liu et al.: Proteomics of Neonatal Kidney of IUGR Rats}

correlated with gene expression levels $[45,46]$, which might be the cause of up-regulated expression of IFT family proteins in IUGR neonatal kidneys. However, little is known about its direct transcriptional targets and how it regulates tissue-specific gene expression. Chromatin immunoprecipitation (ChIP)-qPCR will be necessary to investigate the contribution of histone modification at specific gene promoters to gene expression regulation.

\section{Conclusions}

We first depicted the differently expressed proteins in the neonate kidney of IUGR by iTRAQ-based proteomic analysis. We found the aberrant events may occur in IFT, histone modification, oxidative phosphorylation and purine metabolism. These variations may be responsible for the maldevelopment of IUGR kidneys. Our data provided a new insight into kidney development, and may be valuable in furthering our understanding of the pathogenesis of IUGR-induced kidney injury and fetal origin hypertension.

\section{Acknowledgements}

This work was supported by grants (nos. 81370716 and 81571449) from the National Natural Science Foundation of China. We thank Shanghai Applied Protein Technology Co., Ltd. for technological assistance.

\section{Disclosure Statement}

The authors declare that they have no competing interests. We declare that we have no financial and personal relationships with other people or organizations that can inappropriately influence our work. There is no professional or other personal interest in any product, service and/or company that could be construed as influencing the position presented in the manuscript entitled.

\section{References}

1 Gagnon R: Placental insufficiency and its consequences. Eur J Obstet Gynecol Reprod Biol 2003;110:S99-

107.

2 Pryor J: The identification and long term effects of fetal growth restriction. Br J Obstet Gynaecol 1997;104:1116-1122.

-3 Barker D, Eriksson J, Forsn T, Osmond C: Fetal origins of adult disease: Strength of effects and biological basis. Int J Epidemiol 2002;31:1235-1239.

-4 Londhe VA, Maisonet TM, Lopez B, Shin BC, Huynh J, Devaskar SU: Retinoic acid rescues alveolar hypoplasia in the calorie-restricted developing rat lung. Am J Respir Cell Mol Biol 2013;48:179-187.

-5 Gray C, Al-Dujaili EA, Sparrow AJ, Gardiner SM, Craigon J, Welham SJ, Gardner DS: Excess maternal salt intake produces sex-specific hypertension in offspring: Putative roles for kidney and gastrointestinal sodium handling. PLoS One 2013;8 .Doi: 10.1371/journal.pone.0072682.

6 Vikse BE, Irgens LM, Leivestad T, Hallan S, Iversen BM: Low birth weight increases risk for end-stage renal disease. J Am Soc Nephrol 2008;19:151-157.

7 Slabiak-Blaz N, Adamczak M, Gut N, Grajoszek A, Nyengaard JR, Ritz E, Wiecek A: Administration of cyclosporine a in pregnant rats - the effect on blood pressure and on the glomerular number in their offspring. Kidney Blood Press Res 2015;40:413-423.

8 Liu X, Gu H, Jiao YS, Miao JN, Yuan ZW, Wang AY. Development of kidney and expression and activity of extracellular signal-regulated kinase in intrauterine growth restriction offspring rats. J Appli Clin Pediatr 2012;27:1316-1319. 


\section{Cellular Physiology Cell Physiol Biochem 2017;44:185-199 \begin{tabular}{l|l|l}
\hline DOI: 10.1159/000484626 & $\begin{array}{l}\text { C) } 2017 \text { The Author(s). Published by S. Karger AG, Basel } \\
\text { www.karger.com/cpb }\end{array}$ \\
\hline
\end{tabular}}

Liu et al.: Proteomics of Neonatal Kidney of IUGR Rats

9 Schreuder MF, Van Wijk JA, Fodor M, Delemarre-van de Waal HA: Influence of intrauterine growth restriction on renal function in the adult rat. J Physiol Biochem 2007;63:213-219.

10 Barnes SK, Ozanne SE: Pathways linking the early environment to long-term health and lifespan. Prog Biophys Mol Biol 2011;106:323-336.

-11 Nuyt AM, Alexander BT: Developmental programming and hypertension. Curr Opin Nephrol Hypertens 2009;18:144-152.

12 Pladys P, Lahaie I, Cambonie G, Thibault G, Le NLO, Abran D, Nuyt AM: Role of brain and peripheral angiotensin ii in hypertension and altered arterial baroreflex programmed during fetal life in rat. Pediatr Res 2004;55:1042-1049.

-13 Nuyt AM: Mechanisms underlying developmental programming of elevated blood pressure and vascular dysfunction: Evidence from human studies and experimental animal models. Clin Sci 2008;114:117.

14 Khorram 0, Momeni M, Desai M, Ross MG: Nutrient restriction in utero induces remodeling of the vascular extracellular matrix in rat offspring. Reprod Sci 2007;14:73-80.

15 Brawley L, Itoh S, Torrens C, Barker A, Bertram C, Poston L, Hanson M: Dietary protein restriction in pregnancy induces hypertension and vascular defects in rat male offspring. Pediatr Res 2003;54:83-90.

16 Armitage JA, Lakasing L, Taylor PD, Balachandran AA, Jensen RI, Dekou V, Ashton N, Nyengaard JR, Poston L: Developmental programming of aortic and renal structure in offspring of rats fed fat-rich diets in pregnancy. J Physiol 2005;565:171-184.

17 Mohn A, Chiavaroli V, Cerruto M, Blasetti A, Giannini C, Bucciarelli T, Chiarelli F: Increased oxidative stress in prepubertal children born small for gestational age. J Clin Endocrinol Metab 2007;92:1372-1378.

18 Franco MC, Kawamoto EM, Gorjão R, Rastelli VM, Curi R, Scavone C, Sawaya AL, Fortes ZB, Sesso R: Biomarkers of oxidative stress and antioxidant status in children born small for gestational age: Evidence of lipid peroxidation. Pediatr Res 2007;62:204-208.

19 Racasan S, Braam B, van der Giezen DM, Goldschmeding R, Boer P, Koomans HA, Joles JA: Perinatal l-arginine and antioxidant supplements reduce adult blood pressure in spontaneously hypertensive rats. Hypertension 2004;44:83-88.

20 Boguszewski MC, Johannsson G, Fortes LC, Sverrisdóttir YB: Low birth size and final height predict high sympathetic nerve activity in adulthood. J Hypertens 2004;22:1157-1163.

21 Weitz G, Deckert P, Heindl S, Struck J, Perras B, Dodt C: Evidence for lower sympathetic nerve activity in young adults with low birth weight. J Hypertens 2003;21:943-950.

22 Grigore D, Ojeda NB, Alexander BT: Sex differences in the fetal programming of hypertension. Gend Med 2008;5:S121-S132.

-23 Woods LL, Ingelfinger JR, Rasch R: Modest maternal protein restriction fails to program adult hypertension in female rats. Am J Physiol Regul Integr Comp Physiol 2005;289:R1131-R1136.

-24 Ong ACM, Harris PC: A polycystin-centric view of cyst formation and disease: The polycystins revisited. Kidney Int 2015;88:699-710.

-25 Liu X, Qi Y, Gao H, Jiao Y, Gu H, Miao J, Yuan Z: Maternal protein restriction induces alterations in insulin signaling and atp sensitive potassium channel protein in hypothalami of intrauterine growth restriction fetal rats. J Clin Biochem Nutr 2013;52:43-48.

-26 Wisniewski JR, Zougman A, Nagaraj N, Mann M: Universal sample preparation method for proteome analysis. Nature Methods 2009;6:359-362.

27 Gotz S, Garcia-Gomez JM, Terol J, Williams TD, Nagaraj SH, Nueda MJ, Robles M, Talon M, Dopazo J, Conesa A: High-throughput functional annotation and data mining with the blast2go suite. Nucleic Acids Res 2008;36:3420-3435.

-28 Ashburner M, Ball CA, Blake JA, Botstein D, Butler H, Cherry JM, Davis AP, Dolinski K, Dwight SS, Eppig JT, Harris MA, Hill DP, Issel-Tarver L, Kasarskis A, Lewis S, Matese JC, Richardson JE, Ringwald M, Rubin GM, Sherlock G: Gene ontology: Tool for the unification of biology. The gene ontology consortium. Nat Genet 2000;25:25-29.

29 Kanehisa M, Goto S, Sato Y, Furumichi M, Tanabe M: Kegg for integration and interpretation of large-scale molecular data sets. Nucleic Acids Res 2012;40:D109-114.

30 Shi Z, Zhao C, Long W, Ding H, Shen R: Microarray expression profile analysis of long non-coding rnas in umbilical cord plasma reveals their potential role in gestational diabetes-induced macrosomia. Cell Physiol Biochem 2015;36:542-554. 


\section{Cellular Physiology Cell Physiol Biochem 2017;44:185-199 \begin{tabular}{l|l|l}
\hline and Biochemist 10.1159/000484626 & $\begin{array}{l}\text { C) } 2017 \text { The Author(s). Published by S. Karger AG, Basel } \\
\text { www.karger.com/cpb }\end{array}$ \\
\hline Published online: November 07, 2017
\end{tabular}}

Liu et al.: Proteomics of Neonatal Kidney of IUGR Rats

31 Towbin H, Staehelin T, Gordon J: Electrophoretic transfer of proteins from polyacrylamide gels to nitrocellulose sheets: Procedure and some applications. Proc Natl Acad Sci U S A 1979;76:4350-4354.

-32 Pfaffl MW, Tichopad A, Prgomet C, Neuvians TP: Determination of stable housekeeping genes, differentially regulated target genes and sample integrity: Bestkeeper--excel-based tool using pair-wise correlations. Biotechnol Lett 2004;26:509-515.

-33 Carr G, Moochhala SH, Eley L, Vandewalle A, Simmons NL, Sayer JA: The pyrophosphate transporter ankh is expressed in kidney and bone cells and colocalises to the primary cilium/basal body complex. Cell Physiol Biochem 2009;24:595-604.

-34 Jensen EC: Quantitative analysis of histological staining and fluorescence using imagej. Anat Rec 2013;296:378-381.

35 Pazour GJ, Rosenbaum JL: Intraflagellar transport and cilia-dependent diseases. Trends Cell Biol 2002;12:551-555.

-36 Saito S, Tampe B, Müller GA, Zeisberg M: Primary cilia modulate balance of canonical and non-canonical wnt signaling responses in the injured kidney. Fibrogenesis Tissue Repair 2015;8:6. Doi: 10.1186/s13069015-0024-y.

37 Basten SG, Giles RH: Functional aspects of primary cilia in signaling, cell cycle and tumorigenesis. Cilia 2013;2:6. Doi: 10.1186/2046-2530-2-6.

-38 Robert A, Margall-Ducos G, Guidotti J-E, Brégerie O, Celati C, Bréchot C, Desdouets C: The intraflagellar transport component ift88/polaris is a centrosomal protein regulating g1-s transition in non-ciliated cells. J Cell Sci 2007;120:628-637.

-39 Hamamoto R, Furukawa Y, Morita M, Iimura Y, Silva FP, Li M, Yagyu R, Nakamura Y: Smyd3 encodes a histone methyltransferase involved in the proliferation of cancer cells. Nat Cell Biol 2004;6:731-740.

-40 Van Aller GS, Reynoird N, Barbash O, Huddleston M, Liu S, Zmoos A-F, McDevitt P, Sinnamon R, Le B, Mas G, Annan R, Sage J, Garcia BA, Tummino PJ, Gozani O, Kruger RG: Smyd3 regulates cancer cell phenotypes and catalyzes histone h4 lysine 5 methylation. Epigenetics 2012;7:340-343.

41 Fujii T, Tsunesumi S-i, Yamaguchi K, Watanabe S, Furukawa Y: Smyd3 is required for the development of cardiac and skeletal muscle in zebrafish. PLoS ONE 2011;6:e23491.

42 Pan G, Tian S, Nie J, Yang C, Ruotti V, Wei H, Jonsdottir GA, Stewart R, Thomson JA: Whole-genome analysis of histone h3 lysine 4 and lysine 27 methylation in human embryonic stem cells. Cell Stem Cell 2007;1:299312.

43 Zhao XD, Han X, Chew JL, Liu J, Chiu KP, Choo A, Orlov YL, Sung WK, Shahab A, Kuznetsov VA, Bourque G, Oh S, Ruan Y, Ng HH, Wei CL: Whole-genome mapping of histone h3 lys4 and 27 trimethylations reveals distinct genomic compartments in human embryonic stem cells. Cell Stem Cell 2007;1:286-298.

44 Shilatifard A: The compass family of histone h3k4 methylases: Mechanisms of regulation in development and disease pathogenesis. Annu Rev Biochem 2012;81:65-95.

45 Barski A, Cuddapah S, Cui K, Roh TY, Schones DE, Wang Z, Wei G, Chepelev I, Zhao K: High-resolution profiling of histone methylations in the human genome. Cell 2007;129:823-837.

-46 Pokholok DK, Harbison CT, Levine S, Cole M, Hannett NM, Lee TI, Bell GW, Walker K, Rolfe PA, Herbolsheimer E, Zeitlinger J, Lewitter F, Gifford DK, Young RA: Genome-wide map of nucleosome acetylation and methylation in yeast. Cell 2005;122:517-527. 